\title{
Differential Effects of Natural Palygorskite and its Modified Form on Alleviation of Heavy Metals Toxicity to Tomato Grown in Soil Contaminated with $\mathrm{Cd}, \mathrm{Pb}$ and $\mathrm{Zn}$
}

\author{
Shuli Li ${ }^{1}$, Ningfei Lei ${ }^{1 *}$, Jinsong Chen ${ }^{2}$ \\ ${ }^{1}$ College of Environment, Chengdu University of Technology, Chengdu 610059, China \\ ${ }^{2}$ College of Life Science, Sichuan Normal University, Chengdu 610101, China
}

Received: 2 July 2018

Accepted: 4 September 2018

\begin{abstract}
A field experiment was conducted to investigate differential effects of natural palygorskite (PAL) and its modified form (KH550-PAL) on the alleviation of heavy metals toxicity to tomatos grown in contaminated soil with $\mathrm{Cd}, \mathrm{Pb}$ and $\mathrm{Zn}$. Compared to heavy metal-contaminated soil without amendment, the application of natural palygorskite (PAL) or its modified form (KH550-PAL) significantly alleviated heavy metal toxicity to tomato. In addition, foliar malondialdehyde (MDA), hydrogen peroxide $\left(\mathrm{H}_{2} \mathrm{O}_{2}\right)$ and superoxide $\left(\mathrm{O}_{2}^{-}\right)$contents as well as non-photochemical quenching (NPQ) reduced by 89 , 28,71 , and $81 \%$, respectively, in the modified palygorskite treatment than in the natural palygorskite treatment. Similar patterns were observed in heavy metals uptake of tomato. Foliar superoxide dismutase (SOD), catalase (CAT) and glutathione reductase (GR) activities increased by 228, 196 and 238\%, respectively, in the modified palygorskite treatment than in the natural palygorskite treatment. Thus, the application of the modified form (KH550-PAL) significantly ameliorated the oxidative stress via enhancing antioxidant defense and reducing thermal dissipation, which further improved photosynthetic electron transport of photosystem II and biomass accumulation of tomato. However, the dose of the modified palygorskite (KH550-PAL) was not enough to buffer negative effects of heavy metal toxicity to tomato growth in the experiment. It is suggested that the amendment dose should be used with great care in remediating contaminated soils with heavy metals. Thus, further experiments are needed by different rates of the modified palygorskite (KH550-PAL).
\end{abstract}

Keywords: soil amendment, reactive oxygen species, antioxidant enzyme, chlorophyll fluorescence parameter

*e-mail: 470226504@qq.com 


\section{Introduction}

Soil pollution with heavy metals such as cadmium $(\mathrm{Cd})$, lead $(\mathrm{Pb})$, and zinc $(\mathrm{Zn})$ has become a serious issue in the world [1-2]. Because they can accumulate in the food crops and contaminate the whole food chain, heavy metals cause serious health hazards [3]. Immobilizing toxic heavy metals from soil with plant growth-friendly soil amendments may reduce the potential risks to humans [4]. For example, lime and red mud were effective in reducing $\mathrm{Zn}, \mathrm{Pb}, \mathrm{Ni}, \mathrm{Cd}$, and $\mathrm{Cu}$ uptake for Festuca rubra [5]; biochar increased soil $\mathrm{pH}$, further decreasing the heavy metal bioavailability and uptake by plants [6]. Heavy metal accumulation in plants grown in contaminated soil is usually employed to assess the suitability and effectiveness of soil amendments

Heavy metals (such as $\mathrm{Cd}, \mathrm{Pb}$ or $\mathrm{Zn}$ ) are highly toxic to plants and inhibit their growth, and can even result in death [7]. Heavy metals accumulate readily in plants and their toxicity damages plant infrastructure by necrosis, altered stomatal movement, ion homeostasis, changed metabolism, and affects activities of several key enzymes [8]. Reactive oxygen species (ROS) (i.e., superoxide $\mathrm{O}_{2}^{--}$and hydrogen peroxide $\mathrm{H}_{2} \mathrm{O}_{2}$ ) and malondialdehyde (MDA, a product of lipid peroxidation) produced in response to heavy metal toxicity, causing damage to biomolecules and biomembranes, including nucleic acids by oxidizing proteins and peroxidizing lipids when plants were grown in contaminated soil with $\mathrm{Cd}, \mathrm{Pb}$ or $\mathrm{Zn}$ [9]. Meanwhile, overproduction of reactive oxygen species (ROS) could inhibit photosynthetic electron transport of photosystem II (such as a decrease of $F_{v} / F_{m}$ and $\left.\Phi P S I I\right)$, which reduced the growth of plants subjected to heavy metal stress [10]. So, there is a growing interest to investigate the effects of amendments on alleviation of heavy metal toxicity to plants grown in contaminated soil [11]. This may provide comprehensive understanding on the suitability and effectiveness of amendment application in contaminated soil with heavy metals.

ROS accumulation is balanced by various enzymatic and non-enzymatic defense systems [12]. Increases of non-photochemical quenching (NPQ) could dissipate excess light and protect leaves against photodamage when a plant was grown in contaminated soil with heavy metals [13]. Antioxidant enzymes [i.e., superoxide dismutase (SOD), peroxidase (POD), catalase (CAT) and glutathione reductase (GR)] were employed to protect plant cells against oxidative damage from the overproduction of ROS [14-15].

Natural palygorskite (PAL) reduced Cd concentration and increased biomass accumulation of plants grown in contaminated soil [16]. Palygorskite modification with silane coupling agent (KH-550) presents more network structures and ion channels for adsorbing heavy metal [17]. So it was hypothesized that compared to natural palygorskite (PAL), its modified form (KH550-PAL) was more effective in alleviating heavy metal toxicity for plants grown in contaminated soil with $\mathrm{Cd}, \mathrm{Pb}$ and $\mathrm{Zn}$.

A field experiment was conducted to investigate differential effects of natural palygorskite (PAL) and its modified form (KH550-PAL) on foliar $\mathrm{O}_{2}{ }^{-}$ production rate, $\mathrm{H}_{2} \mathrm{O}_{2}$ and MDA contents, antioxidant enzyme activities, chlorophyll fluorescence parameters of tomatos grown in contaminated soil with $\mathrm{Cd}, \mathrm{Pb}$ and $\mathrm{Zn}$ as well as heavy metals concentration, bioconcentration factor (BCF) of heavy metals and biomass accumulation of root, shoot and leaf. The aim of our study is to evaluate and compare the potential of natural palygorskite (PAL) and its modified form (KH550-PAL) 1) in reducing heavy metals uptake by plants grown in contaminated soil with $\mathrm{Cd}, \mathrm{Pb}$ and $\mathrm{Zn}$; 2) alleviating heavy metals toxicity in plants grown in contaminated soil with $\mathrm{Cd}, \mathrm{Pb}$ and $\mathrm{Zn}$. The research will help formulate strategies regarding the management of heavy metal-contaminated soils.

\section{Material and Methods}

\section{Experimental Site}

A field experiment was conducted in Ganlo County $\left(102^{\circ} 27^{\prime} E \sim 28^{\circ} 38^{\prime} N\right)$, Sichuan Province, China. Annual temperature, annual rainfall and relative humidity is $16^{\circ} \mathrm{C} \sim 17^{\circ} \mathrm{C}, 860.3 \mathrm{~mm}$ and $68 \%$, respectively. historical lead-zinc smelting and mining he soil was polluted with $\mathrm{Pb}, \mathrm{Cd}$ and $\mathrm{Zn}$ [17].

\section{Preparing Soil Amendments}

Natural palygorskite (PAL) and its modified form (KH550-PAL) were utilized as amendments for remediating contaminated soil with $\mathrm{Cd}, \mathrm{Pb}$ and $\mathrm{Zn}$. Chemical composition of natural palygorskite (PAL)

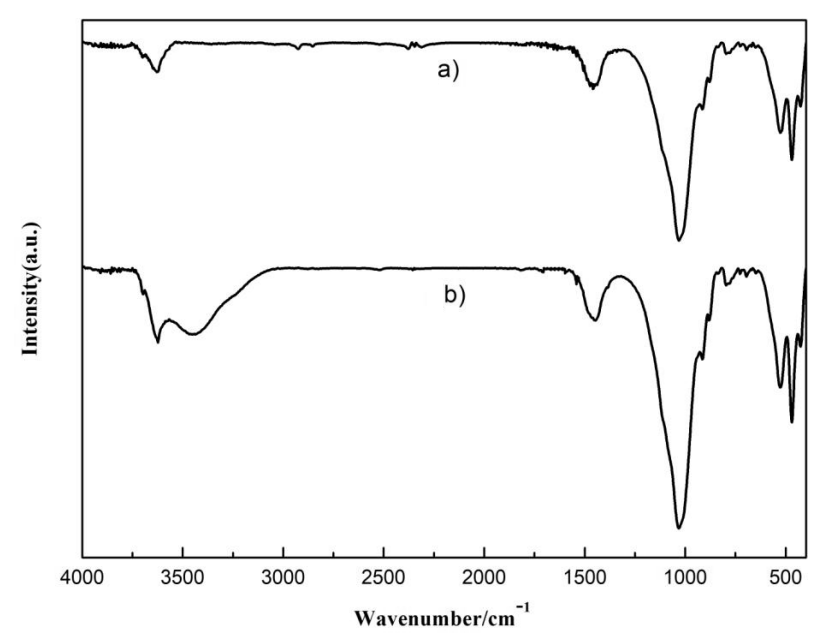

Fig. 1. FTIR spectra of natural palygorskite (PAL) and modified palygorskite (KH550-PAL): a) natural palygorskite (PAL), b) modified palygorskite (KH550-PAL). 


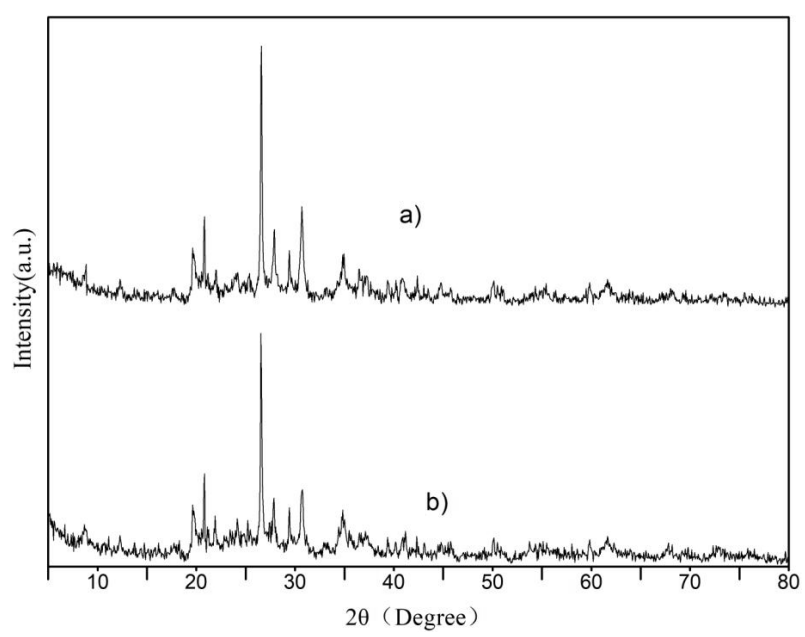

Fig. 2. XRD patterns of natural palygorskite (PAL) and modified palygorskite (KH550-PAL): a) natural palygorskite (PAL), b) modified palygorskite (KH550-PAL).

consisted of $51.1 \% \mathrm{SiO}_{2}, 15.5 \% \mathrm{MgO}, 14.5 \% \mathrm{CaO}$, $9.9 \% \quad \mathrm{Al}_{2} \mathrm{O}_{3}$ and $1.2 \% \quad \mathrm{Na}_{2} \mathrm{O}$. Modified-palygorskite was synthesized by chemical method using silane coupling agent (KH550) [18]. Fourier transmission infrared (FTIR) and x-ray diffraction (XRD) methods were employed to analyze the structure of natural palygorskite (PAL) and its modified form (KH550-PAL). For FTIR of modified palygorskite, $\mathrm{C}-\mathrm{H}$ stretching bands appeared at $2926.58 \mathrm{~cm}^{-1}$, confirming the presence of $\mathrm{C}-\mathrm{H}$ stretching bands of both $\mathrm{CH}_{3}$ and $\mathrm{CH}_{2}$ groups of alkylammonium cations. The FTIR results proved the surface modification of natural palygorskite (PAL) at $\mathrm{Si}-\mathrm{O}$ centers (Fig. 1). The XRD results demonstrated that modification did not destroy the crystal structure of natural palygorskite (PAL) and KH-550 merely adhered to its exterior (Fig. 2).

\section{Experimental Design}

Four treatments, in a random block design with six replicates per treatment, were set up in experimental plots of $4 \mathrm{~m}^{2}$ each, with $0.5 \mathrm{~m}$ distance between plots. The treatments included: (I) uncontaminated soil (Control), (II) heavy metals-contaminated soil without the application of amendment (HMS), (III) $1 \%(\mathrm{w} / \mathrm{w})$ natural palygorskite (PAL) was applied to contaminated soil based on the mass of top $20 \mathrm{~cm}$ soil (PAL), and (IV) $1 \%(\mathrm{w} / \mathrm{w})$ modified palygorskite (KH550-PAL) was applied to contaminated soil based on the mass of top $20 \mathrm{~cm}$ soil (KH550-PAL). The composition of uncontaminated soil is similar to that of contaminated soil with heavy metals and because the former was collected from a nearby site free of heavy metals pollution.

Soil amendments (natural palygorskite (PAL) and its modified form (KH550-PAL)) were hand-scattered on the soil surface and then plowed into the soil. After 60 days, soil samples were air dried, ground and sieved through $2 \mathrm{~mm}$. Soil $\mathrm{pH}$ was determined in 1:2.5 soil/ water suspensions after $0.5 \mathrm{~h}$ with a combination $\mathrm{pH}$ electrode. Total $\mathrm{N}$ and $\mathrm{C}$, available $\mathrm{K}$ and $\mathrm{P}$ of soil samples were analyzed as described by Zhao et al. [19]. The concentration of total heavy metals $(\mathrm{Pb}, \mathrm{Cd}$ and $\mathrm{Zn})$ in the soil samples were measured after mineralization with $\mathrm{HNO}_{3}$ and $\mathrm{HCl}$ (ratio 1/3) using a Microwave Milestone MLS 1200 [20]. The soil properties are displayed in Table 1.

Then, 9 tomato seedlings with uniform size (4-leaf stage) were transplanted to each plot. Before transplanting, a dose of $200 \mathrm{~kg} \mathrm{ha}^{-1}$ of $12-17-17$ $\left(\mathrm{N}-\mathrm{P}_{2} \mathrm{O}_{5}-\mathrm{K}_{2} \mathrm{O}\right)$ mineral fertilizer was added to each plot. The plots were managed according to conventional operating practices. The experiment lasted for two months.

At the end of the experiment, 3 plants per plot were randomly selected. A fully expanded leaf of each plant was chosen to measure chlorophyll fluorescence parameters with a portable fluorescence induction monitor (FMS-2, Hansatech Instruments Ltd., UK). Foliar antioxidant enzyme activities, $\mathrm{O}_{2}^{-}$-production rate, $\mathrm{H}_{2} \mathrm{O}_{2}$ and MDA contents were determined using the leaf. After harvesting, the plant was separated into root, shoot and leaf. After oven drying at $60^{\circ} \mathrm{C}$, their dry weights

Table 1. Soil properties in different treatments.

\begin{tabular}{|c|c|c|c|c|c|c|c|c|}
\hline \multirow{2}{*}{$\begin{array}{c}\text { Treat- } \\
\text { ment }\end{array}$} & $\mathrm{pH}$ & $\begin{array}{c}\text { Total } \\
\text { nitrogen } \\
(\mathrm{mg} / \mathrm{kg})\end{array}$ & $\begin{array}{c}\text { Total } \\
\text { carbon } \\
(\mathrm{mg} / \mathrm{kg})\end{array}$ & $\begin{array}{c}\mathrm{P}_{\text {CAL }} \\
(\mathrm{mg} / \mathrm{kg})\end{array}$ & $\begin{array}{c}\mathrm{K}_{\text {CAL }} \\
(\mathrm{mg} / \mathrm{kg})\end{array}$ & $\begin{array}{c}\text { Total Cd } \\
(\mathrm{mg} / \mathrm{kg})\end{array}$ & $\begin{array}{c}\text { Total Pb } \\
(\mathrm{mg} / \mathrm{kg})\end{array}$ & $\begin{array}{c}\text { Total Zn } \\
(\mathrm{mg} / \mathrm{kg})\end{array}$ \\
\hline Control & $6.74 \pm 0.04^{\mathrm{c}}$ & $2.40 \pm 0.03^{\mathrm{a}}$ & $31.93 \pm 0.28^{\mathrm{a}}$ & $5.71 \pm 0.08^{\mathrm{a}}$ & $41.18 \pm 0.65^{\mathrm{a}}$ & $0.09 \pm 0.01^{\mathrm{c}}$ & $105.09 \pm 5.91^{\mathrm{b}}$ & $92.61 \pm 8.33^{\mathrm{c}}$ \\
\hline HMS & $5.38 \pm 0.03^{\mathrm{d}}$ & $2.23 \pm 0.02^{\mathrm{b}}$ & $30.16 \pm 0.16^{\mathrm{b}}$ & $5.21 \pm 0.04^{\mathrm{c}}$ & $39.75 \pm 1.34^{\mathrm{b}}$ & $12.40 \pm 0.12^{\mathrm{a}}$ & $1109.67 \pm 17.86^{\mathrm{a}}$ & $1223.02 \pm 31.92^{\mathrm{a}}$ \\
\hline PAL & $6.82 \pm 0.04^{\mathrm{b}}$ & $2.19 \pm 0.02^{\mathrm{c}}$ & $29.75 \pm 0.52^{\mathrm{c}}$ & $5.66 \pm 0.03^{\mathrm{b}}$ & $34.52 \pm 0.68^{\mathrm{c}}$ & $12.26 \pm 0.08^{\mathrm{ab}}$ & $1089.56 \pm 21.53^{\mathrm{a}}$ & $1198.67 \pm 27.69^{\mathrm{b}}$ \\
\hline $\begin{array}{c}\text { KH550- } \\
\text { PAL }\end{array}$ & $7.03 \pm 0.06^{\mathrm{a}}$ & $2.18 \pm 0.01^{\mathrm{c}}$ & $29.78 \pm 0.88^{\mathrm{c}}$ & $5.65 \pm 0.05^{\mathrm{b}}$ & $34.57 \pm 1.22^{\mathrm{c}}$ & $12.03 \pm 0.07^{\mathrm{b}}$ & $1081.89 \pm 19.07^{\mathrm{a}}$ & $1187.33 \pm 17.41^{\mathrm{b}}$ \\
\hline
\end{tabular}

The treatments included: (I) uncontaminated soil (Control), (II) heavy metals contaminated soil without application of amendment (HMS), (III) 1\% (w/w) natural palygorskite (PAL) was applied to contaminated soil based on the mass of top $20 \mathrm{~cm}$ soil (PAL), (IV) $1 \%(\mathrm{w} / \mathrm{w})$ modified palygorskite (KH550-PAL) was applied to contaminated soil based on the mass of top $20 \mathrm{~cm}$ soil (KH550-PAL). In each column, data with different lower case letters are significantly different at $p=0.05$ 
(g) were recorded until constant weight was obtained. A mean of 3 measurements from each plot was recorded as a replication.

\section{Reactive Oxygen Species $\left(\mathrm{O}_{2} \bullet\right.$ - Production Rate and $\mathrm{H}_{2} \mathrm{O}_{2}$ Content)}

Hydrogen peroxide $\left(\mathrm{H}_{2} \mathrm{O}_{2}\right)$ content was estimated following the method of titanium tetrachloride [21]. Fresh leaves $(0.2 \mathrm{~g})$ were homogenized with $5 \mathrm{~mL}$ of ice-cold acetone and then centrifuged at $3000 \mathrm{~g}$ for $10 \mathrm{~min}$ at $4^{\circ} \mathrm{C}$. The reactive mixture contained $0.1 \mathrm{~mL}$ of $20 \%(\mathrm{v} / \mathrm{v})$ titanium tetrachloride in the concentrated hydrochloric acid, $0.2 \mathrm{~mL}$ of ammonia, and $1 \mathrm{~mL}$ of the supernatant, which was then centrifuged at $3000 \mathrm{~g}$ for $10 \mathrm{~min}$. The resulting pellet was washed five times with ice-cold acetone, having been resuspended. The pellet was then dissolved in $3 \mathrm{~mL}$ of $1 \mathrm{M} \mathrm{H}_{2} \mathrm{SO}_{4}$ and finally measured at $410 \mathrm{~nm}$. The $\mathrm{H}_{2} \mathrm{O}_{2}$ concentration was calculated according to the calibration curve constructed using known concentrations.

$\mathrm{O}_{2}^{-}$production rate was determined as described by Liu et al. [22]. Fresh leaves $(0.2 \mathrm{~g})$ were homogenized with $2 \mathrm{~mL}$ of $65 \mathrm{mM}$ ice-cold sodium phosphate buffer $(\mathrm{pH} \mathrm{7.8)}$ and then centrifuged at $5000 \mathrm{~g}$ for $10 \mathrm{~min}$ at $4^{\circ} \mathrm{C}$. One $\mathrm{mL}$ of the supernatant was mixed with $0.9 \mathrm{~mL}$ of $65 \mathrm{mM}$ sodium phosphate buffer $(\mathrm{pH} 7.8)$ and $0.1 \mathrm{~mL}$ of $10 \mathrm{mM}$ hydroxylammonium chloride. The reactive mixture was incubated for $20 \mathrm{~min}$ at $25^{\circ} \mathrm{C}$. One $\mathrm{mL}$ of the above solution was mixed with $1 \mathrm{~mL}$ of $17 \mathrm{mM}$ 4-aminobenzenesulfonic acid and $1 \mathrm{~mL}$ of $7 \mathrm{mM} \alpha$-naphthylamine, kept for $20 \mathrm{~min}$ at $25^{\circ} \mathrm{C}$, and finally quantified at $530 \mathrm{~nm}$.

\section{Malondialdehyde (MDA) Content}

Fresh leaves $(0.2 \mathrm{~g})$ were homogenized with $2 \mathrm{~mL}$ of $50 \mathrm{mM}$ ice cold sodium phosphate buffer $(\mathrm{pH}$ 7.8) and then centrifuged at $12000 \mathrm{~g}$ for $20 \mathrm{~min}$ at $4^{\circ} \mathrm{C}$. One $\mathrm{mL}$ of the supernatant was mixed with $3 \mathrm{~mL}$ of $20 \%(\mathrm{w} / \mathrm{v})$ TCA solution containing $2 \%(\mathrm{w} / \mathrm{v})$ TBA. The reactive mixture was incubated for $30 \mathrm{~min}$ in a $95^{\circ} \mathrm{C}$ water bath, rapidly cooled in an ice bath, and then centrifuged at $15000 \mathrm{~g}$ for $10 \mathrm{~min}$. The absorbance was recorded at $532 \mathrm{~nm}$ and $600 \mathrm{~nm}$.

\section{Antioxidant Enzyme Activities}

In order to extract the antioxidant enzymes, $0.2 \mathrm{~g}$ of frozen leaves were extracted with $2 \mathrm{~mL}$ of $50 \mathrm{mM}$ ice cold sodium phosphate buffer ( $\mathrm{pH}$ 7.8) containing $0.2 \mathrm{mM}$ EDTA, 2\% (w/v) polyvinylpyrrolidone (PVP), and $2 \mathrm{mM}$ reduced ascorbate (AsA). The extract was centrifuged at $12000 \mathrm{~g}$ for $20 \mathrm{~min}$ at $4^{\circ} \mathrm{C}$. Then the supernatant was immediately used to measure the activities of the antioxidant enzyme listed below.

CAT activity was analyzed according to Cakmak and Marschner [23] by following the decomposition of $\mathrm{H}_{2} \mathrm{O}_{2}$ at $240 \mathrm{~nm}(\varepsilon=39.4 /(\mathrm{mM} \mathrm{cm}))$. The reactive mixture contained $1.7 \mathrm{~mL}$ of $25 \mathrm{mM}$ sodium phosphate buffer with $0.1 \mathrm{mM}$ EDTA ( $\mathrm{pH} 7.0$ ), $0.2 \mathrm{~mL}$ of $10 \mathrm{mM}$ $\mathrm{H}_{2} \mathrm{O}_{2}$, and $0.1 \mathrm{~mL}$ of the supernatant.

POD activity was determined by monitoring the decomposition of $\mathrm{H}_{2} \mathrm{O}_{2}$ at $470 \mathrm{~nm}(\varepsilon=26.6 /(\mathrm{mM} \mathrm{cm}))$ [23]. The reactive mixture contained $1.7 \mathrm{~mL}$ of $25 \mathrm{mM}$ sodium phosphate buffer with $0.1 \mathrm{mM}$ EDTA ( $\mathrm{pH} 7.0$ ), $0.1 \mathrm{~mL}$ of $1 \%$ guaiacol, $0.1 \mathrm{~mL}$ of $20 \mathrm{mM} \mathrm{H}_{2} \mathrm{O}_{2}$, and $0.1 \mathrm{~mL}$ of the supernatant.

GR activity was assayed by following the decrease in the absorbance at $340 \mathrm{~nm}$ caused by NADPH oxidation $(\varepsilon=6.2 /(\mathrm{mM} \mathrm{cm}))$ according to the method of Madamanchi and Alscher [24]. The reactive mixture contained $1.7 \mathrm{~mL}$ of $25 \mathrm{mM}$ sodium phosphate buffer with $0.2 \mathrm{mM}$ EDTA $(\mathrm{pH} 7.8), 0.1 \mathrm{~mL}$ of $2.4 \mathrm{mM}$ NADPH, $0.1 \mathrm{~mL}$ of $10 \mathrm{mM}$ oxidized glutathione (GSSG), and $0.1 \mathrm{~mL}$ of the supernatant.

SOD activity was measured using a previously described photochemical method [25]. The reaction contained supernatant and nitro blue tetrazolium (NBT) solution, including $50 \mathrm{mM}$ SPB $(\mathrm{pH} 7.8), 0.1 \mathrm{mM}$ EDTA, $63 \mathrm{Mm}$ NBT, $13 \mathrm{mM}$ methionine, and $1.3 \mathrm{mM}$ riboflavin. One unit of SOD activity was defined as the amount of enzyme required to cause a $50 \%$ inhibition in the rate of p-nitro blue tetrazolium chloride reduction at $560 \mathrm{~nm}$.

\section{Chlorophyll Fluorescence Parameters}

Foliar chlorophyll fluorescence parameters were measured using a portable, modulated fluorescence monitoring system (FMS-2, Hansatech Instruments Ltd., UK). After determining light-adapted parameters, the plants were fully covered with black opaque plastic bags and maintained for $40 \mathrm{~min}$. and the minimum chlorophyll fluorescence $\left(F_{0}\right)$ was determined using a measuring beam of $0.2 \mu \mathrm{mol} \mathrm{m} \mathrm{m}^{-2} \mathrm{~s}^{-1}$ intensity. A saturation pulse $\left(1 \mathrm{~s}\right.$ white light of $7,500 \mu \mathrm{mol} \mathrm{m} \mathrm{m}^{-2} \mathrm{~s}^{-1}$ intensity) was used to obtain the maximum fluorescence $\left(F_{m}\right)$ after a dark-adapted state, and the maximum photochemical efficiency of PSII $\left(F_{v} / F_{m}\right)$ was recorded. Light-induced changes in chlorophyll fluorescence following actinic illumination $\left(300 \mu \mathrm{mol} \mathrm{m} \mathrm{m}^{-2} \mathrm{~s}^{-1}\right)$ were recorded prior to the measurement of $F^{\prime}{ }_{0}$ (minimum chlorophyll a fluorescence in light-saturated state) and $F_{m}^{\prime}$ (maximum fluorescence in light-saturated state), nonphotochemical quenching, photochemical quenching (qP) and non-photochemical quenching (NPQ) were calculated [26].

\section{Heavy Metals Concentrations in Root, Leaf, Shoot}

After drying, roots, leaves and shoots were ground in a mill to a mesh size of $0.5 \mathrm{~mm}$. Then they were digested with di-acid mixture $\left(\mathrm{HNO}_{3}: \mathrm{HClO}_{4}\right.$ ratio of 2:1) respectively and concentrations of $\mathrm{Cd}, \mathrm{Pb}$ and $\mathrm{Zn}$ were measured by AAS [27]. 


\section{Bio-Concentration Factor (BCF) of Heavy Metal}

Bio-concentration factor (BCF) of heavy metal was calculated as shown below:

$\mathrm{BCF}=$ concentration of heavy metal in root $\left(\mathrm{mg} \cdot \mathrm{kg}^{-1}\right) /$ concentration in external environment (mg.kg ${ }^{-1}$ ) [28]

\section{Statistical Analysis}

One-way ANOVA was used to investigate effects of different treatments on foliar $\mathrm{O}_{2}^{--}$production rate, $\mathrm{H}_{2} \mathrm{O}_{2}$ and MDA contents, antioxidant enzyme activities, and chlorophyll fluorescence parameters of tomato as well as heavy metals concentration, bio-concentration factors (BCF) of heavy metals and biomass accumulation of root, shoot and leaf. All analyses were conducted with SPSS 20.0 software (SPSS, Chicago, IL, USA).

\section{Results and Discussion}

Heavy Metals Concentration of Root, Shoot, Leaf and Bio-Concentration Factors (BCF)

The highest heavy metals concentration in root, shoot and leaf were observed when tomato was grown in contaminated soil without the application of amendment (HMS), whereas the lowest values were observed when tomato was grown in uncontaminated soil (Control) (Table 2). Compared to natural palygorskite (PAL), $\mathrm{Pb}$ concentration of root and leaf was significantly decreased by application of its modified form (KH550PAL) when tomato was grown in contaminated soil with $\mathrm{Cd}, \mathrm{Pb}$ and $\mathrm{Zn}$ (Table 2). A similar pattern was observed in $\mathrm{Cd}$ concentrations of roots, shoots and leaves, and $\mathrm{Zn}$ concentrations of shoots and leaves (Table 2). The results are consistent with previous studies [29]. Compared to heavy metals-contaminated soil without amendment, the application of natural palygorskite (PAL) or its modified form (KH550-PAL) significantly reduced the bio-concentration factor of heavy metals in tomato (Table 2). Bio-concentration factors of heavy metals in tomato were significantly decreased by the application of the modified palygorkite (KH550$\mathrm{PAL}$ ) to contaminated soil with $\mathrm{Cd}, \mathrm{Pb}$ and $\mathrm{Zn}$ than the natural one (Table 2). A possible explanation is that the surface of the modified palygorskite (KH550-PAL) has more network structures as functional groups, reacting with heavy metals ions by chemical binding to form inner-sphere complexes [30]. Meanwhile, modification by silane coupling agent (KH550) may enrich the ion channels of natural palygorskite (PAL) for heavy metals sorption and change heavy metals species, which reduces heavy metals uptake by tomato grown in contaminated soil with $\mathrm{Cd}, \mathrm{Pb}$ or $\mathrm{Zn}$ [31].

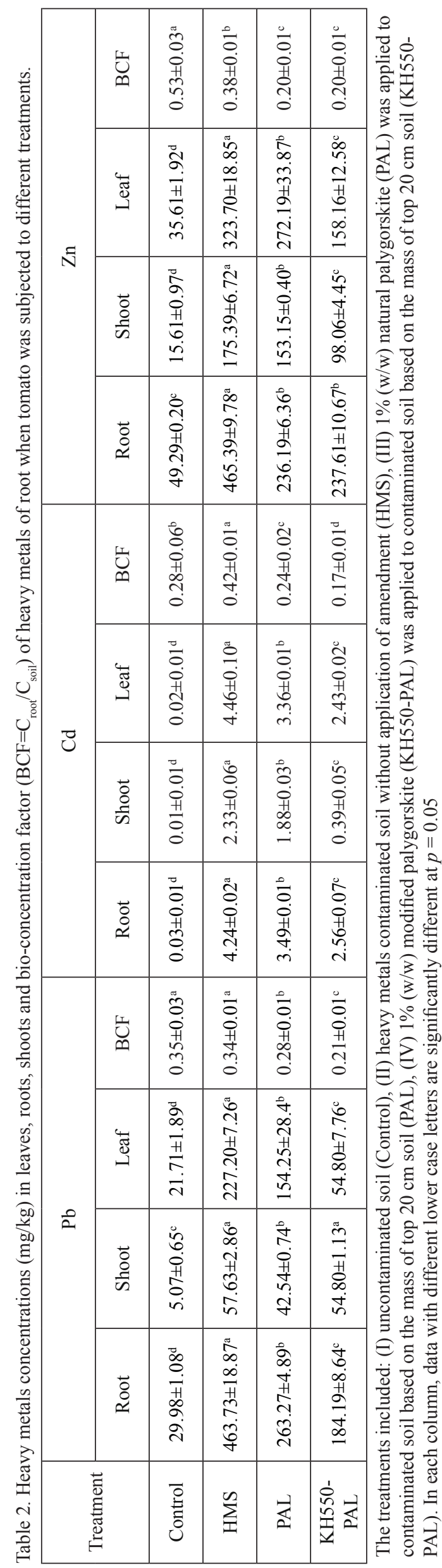




$$
\begin{gathered}
\text { Foliar } \mathrm{O}_{2}^{-} \text {Production Rate, } \mathrm{H}_{2} \mathrm{O}_{2} \\
\text { and MDA Contents }
\end{gathered}
$$

Oxidative stress caused by heavy metals induces membrane injury, retards nutrient uptake capacity and ultimately inhibits plant growth [32]. Malondialdehyde (MDA) is a common product of lipid peroxidation that reflects the extent of oxidative injury [8]. The highest foliar $\mathrm{O}_{2}^{-}$production rate, $\mathrm{H}_{2} \mathrm{O}_{2}$ and MDA contents were observed when tomato was grown in contaminated soil without the application of amendment (HMS) (Fig. 3). Compared to natural palygorskite (PAL), foliar $\mathrm{O}_{2}^{-}$ production rate and MDA content were significantly reduced by the application of its modified form (KH550PAL) when tomato was grown in contaminated soil with $\mathrm{Cd}, \mathrm{Pb}$ and $\mathrm{Zn}$ (Fig. 3a, c). However, a similar pattern was not observed in foliar $\mathrm{H}_{2} \mathrm{O}_{2}$ content (Fig. 3b). Compared to the application of the modified palygorskite (KH550-PAL), no difference was detected in foliar $\mathrm{O}_{2}{ }^{-}$production rate and MDA content of tomato grown in uncontaminated soil (Control) (Fig. 3a, c). It is suggested that due to decreased uptake of heavy metal in tomato grown in contaminated soil with $\mathrm{Cd}, \mathrm{Pb}$ and $\mathrm{Zn}$, oxidative stress is significantly relieved by the application of the modified palygorskite (KH550-PAL) [11].

\section{Foliar Antioxidant Enzyme Activities}

SOD can catalyze the conversion of toxic $\mathrm{O}_{2}{ }^{-}$to $\mathrm{H}_{2} \mathrm{O}_{2}$, which is further reduced to $\mathrm{O}_{2}$ and $\mathrm{H}_{2} \mathrm{O}$ by POD and CAT. GR can also be involved in $\mathrm{H}_{2} \mathrm{O}_{2}$ removal by the activation of the ascorbate-glutathione cycle [33]. Antioxidant enzymes (SOD, POD, GR and CAT) play an important role in detoxifying ROS and alleviating oxidative stress [34]. Compared to tomato grown in uncontaminated soil (Control), foliar antioxidant enzyme (SOD, GR and CAT) activities gradually increased when tomato was grown in contaminated soil without application of amendment (HMS), contaminated soil with the application of natural palygorskite (PAL) and its modified form (KH550-PAL) (Fig. 4a, c, d). The explanation is that soil amendments may enhance defensive resistance against ROS in plants subjected to heavy metal stress. However, the opposite pattern was observed in foliar antioxidant enzyme (POD) activity (Fig. 4b). This indicated that soil amendments could eliminate heavy metal toxicity and the ROS effect by immobilizing ions [11]. Our results imply that the modified palygorskite (KH550-PAL) may induce stronger resistance against heavy metals stress in tomato than natural palygorskite (PAL).
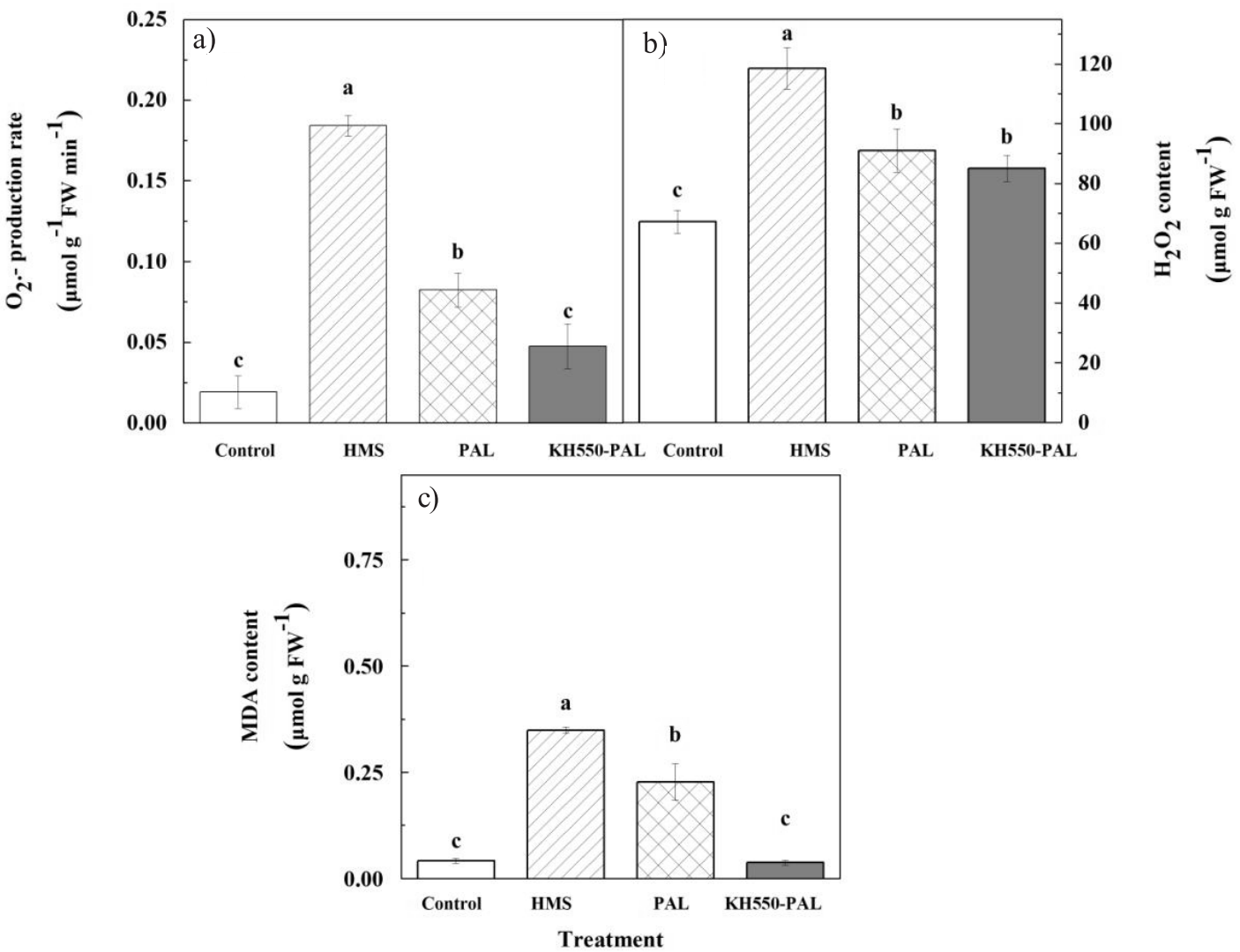

Fig. 3. Foliar $\mathrm{O}_{2}^{--}$production rate, $\mathrm{H}_{2} \mathrm{O}_{2}$ and MDA contents when tomato was subjected to different treatments: (I) uncontaminated soil (Control), (II) heavy metals-contaminated soil without application of amendment (HMS), (III) 1\% (w/w) natural palygorskite (PAL) was applied to contaminated soil based on the mass of top $20 \mathrm{~cm}$ soil (PAL), (IV) $1 \%$ (w/w) modified palygorskite (KH550-PAL) was applied to contaminated soil based on the mass of top $20 \mathrm{~cm}$ soil (KH550-PAL). The bars marked with different lowercase letters are significantly different at $p=0.05$. 


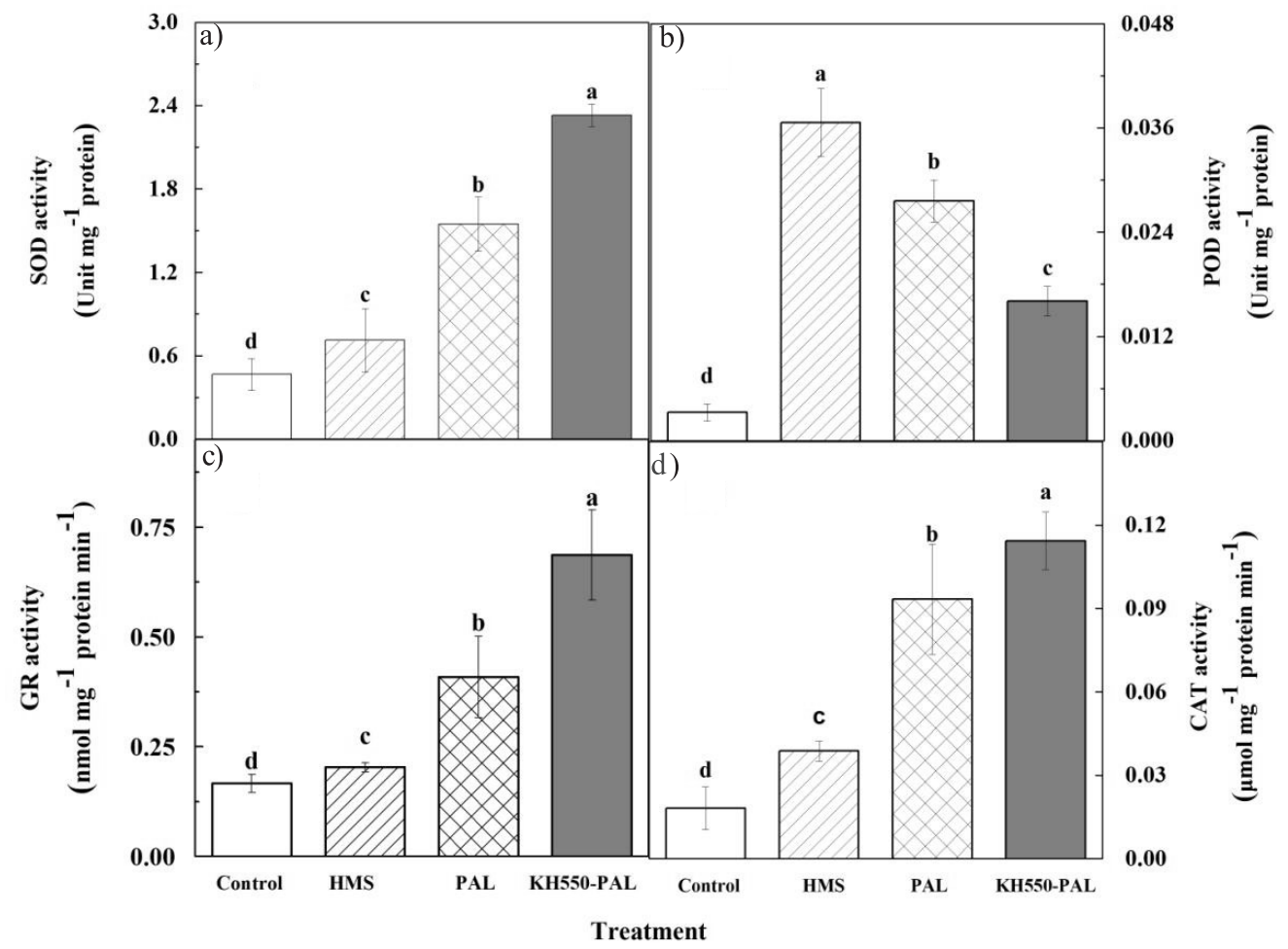

Fig. 4. Foliar antioxidant enzyme activities when tomato was subjected to different treatments: (I) uncontaminated soil (Control), (II) heavy metal contaminated soil without application of amendment (HMS), (III) $1 \%(\mathrm{w} / \mathrm{w}$ ) natural palygorskite (PAL) was applied to contaminated soil based on the mass of top $20 \mathrm{~cm}$ soil (PAL), (IV) $1 \%(\mathrm{w} / \mathrm{w}$ ) modified palygorskite (KH550-PAL) was applied to contaminated soil based on the mass of top $20 \mathrm{~cm}$ soil (KH550-PAL). The bars marked with different lowercase letters are significantly different at $p=0.05$.

\section{Foliar Chlorophyll Fluorescence Parameters}

$\Phi P S I I$ and $F v / F_{m}$ reflect actual photosynthetic efficiency and potential maximum photosynthetic capacity of PSII [26]. Heavy metals stress diminished photochemical capacity of PSII with a decrease of foliar $F_{V} / F_{m}$ and ФPSII in tomato grown in contaminated soil with heavy metals [35]. The lowest foliar $F_{V} / F_{m}$, and $\Phi P S I I$ were observed when tomato was grown in contaminated soil without the application of amendment (HMS) (Fig. 5a-b). Compared to tomato grown in contaminated soil without application of the amendment (HMS), foliar $F_{V} / F_{m}$, and $\Phi P S I I$ of tomato were significantly increased by the application of the modified palygorskite (KH550-PAL) (Fig. 5a-b). However, the application of the modified palygorskite (KH550-PAL) was not enough to relieve negative effects of heavy metals on foliar $F_{V} / F_{m}$, and $\Phi P S I I$ of tomato in the experiment (Fig. 5a-b). The results are consistent with previous study [36].

Photochemical quenching $(q P)$ reflects the number of open reaction centers, which is an indicator of the capacity of photochemical processes. Nonphotochemical quenching $(N P Q)$ represents the heat dissipation of excessive energy within photosystem resulting from environmental stress. The highest foliar $N P Q$ and $q P$ were observed when tomato was grown in heavy metals-contaminated soil without application of the amendment (HMS) (Fig. 5c-d). Compared to natural palysorkite (PAL), foliar $N P Q$ and $q P$ of tomato grown in contaminated soil with $\mathrm{Pb}, \mathrm{Cd}$ and $\mathrm{Zn}$ were significantly decreased by the application of its modified form (KH550-PAL) (Fig. 5c-d). Compared to the application of the modified palygorskite (KH550-PAL), no difference was detected in foliar $N P Q$ and $q P$ of tomato grown in uncontaminated soil (Control) (Fig. 5c-d). This indicated that the application of its modified form (KH550-PAL) could protect PSII against damage/inactivation, which improved the photosystem activity of tomatos grown in contaminated soil with heavy metals [37].

\section{Biomass Accumulation in Root, Shoot and Leaf}

Compared to tomato grown in uncontaminated soil (Control), biomass accumulation in root, shoot and leaf was significantly decreased for tomato grown in heavy metals-contaminated soil without application of amendment (HMS) (Fig. 6), which is consistent with previous study [38]. Compared to natural palygorskite (PAL), the application of its modified form (KH550-PAL) significantly improved biomass accumulation of root, shoot and leaf in tomato grown in heavy metals-contaminated soil with $\mathrm{Pb}, \mathrm{Cd}$ and $\mathrm{Zn}$ (Fig. 6). The results supported our hypothesis. So, the 


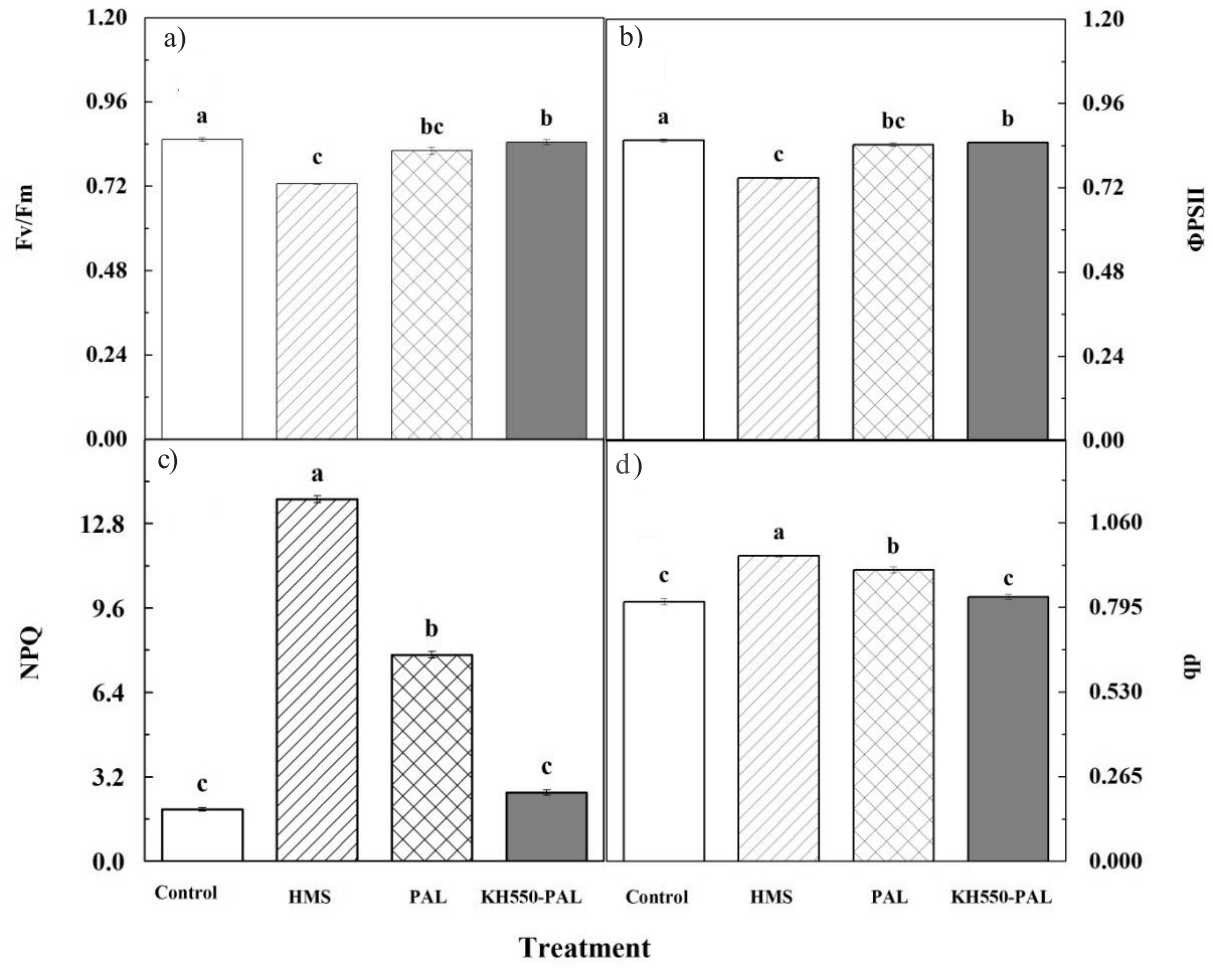

Fig. 5. Foliar chlorophyll fluorescence parameters when tomato was subjected to different treatments: (I) uncontaminated soil (Control), (II) heavy metals contaminated soil without application of amendment (HMS), (III) $1 \%$ (w/w) natural palygorskite (PAL) was applied to contaminated soil based on the mass of top $20 \mathrm{~cm}$ soil (PAL), (IV) $1 \%$ (w/w) modified palygorskite (KH550-PAL) was applied to contaminated soil based on the mass of top $20 \mathrm{~cm}$ soil (KH550-PAL). The bars marked with different lower case letters are significantly different at $p=0.05$.

modified palygorskite is a promising amendment in alleviating heavy metals toxicity and improving growth

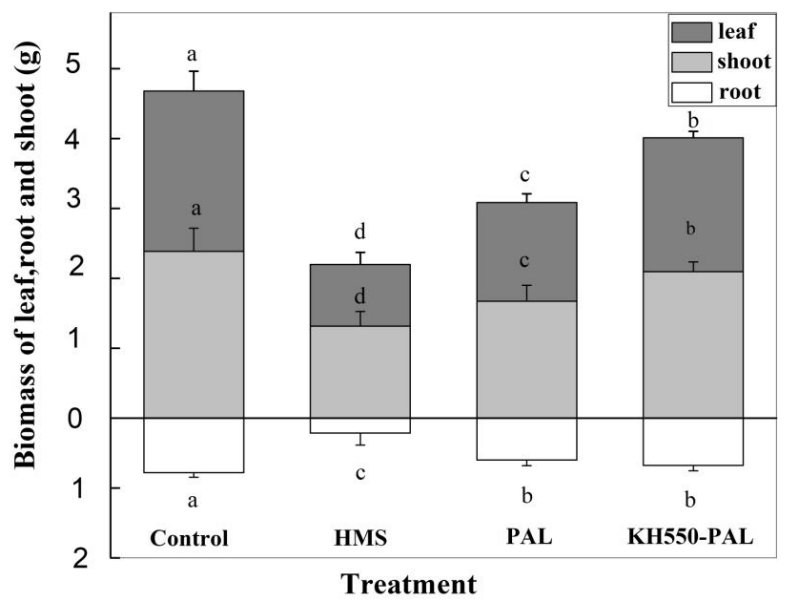

Fig. 6. Biomass of leaf, root and shoot when tomato was subjected to different treatments: (I) uncontaminated soil (Control), (II) heavy metals contaminated soil without application of amendment (HMS), (III) 1\% (w/w) natural palygorskite (PAL) was applied to contaminated soil based on the mass of top $20 \mathrm{~cm}$ soil (PAL), (IV) $1 \%(\mathrm{w} / \mathrm{w}$ ) modified palygorskite (KH550PAL) was applied to contaminated soil based on the mass of top $20 \mathrm{~cm}$ soil (KH550-PAL). The bars marked with different lowercase letters are significantly different at $p=0.05$. performance in plants grown in contaminated soil with $\mathrm{Pb}, \mathrm{Cd}$ and $\mathrm{Zn}$.

\section{Conclusions}

The present study investigated the effects of natural palygorskite or its modified form on alleviating heavy metals toxicity to tomato grown in contaminated soil with $\mathrm{Cd}, \mathrm{Pb}$ and $\mathrm{Zn}$. Our experiment results strongly support the modified palygorskite for soil heavy metals immobilization. It is suggested that minimizing heavy metals bioavailability improves scavenging ROS by enhancing antioxidant defense and reducing thermal dissipation. However, doses of the modified palygorskite were not enough to buffer negative effects of heavy metals toxicity on tomato growth in the experiment. It was suggested that the amendment dose should be used with great care in remediating contaminated soils with heavy metals. Thus, further experiments are needed by different rates of the modified palygorskite.

\section{Acknowledgements}

This project was supported by Education department of Sichuan Province (14ZA0023). 


\section{Conflict of Interest}

The authors declare no conflict of interest.

\section{References}

1. QU C.S., SHI W., GUO J., FANG B.B., WANG S., GIESY J.P., HOLM P.E. China's soil pollution control: choices and challenges. Environment Science Technology, 50, 13181, 2016.

2. ZHAO F.J., MA Y.B., ZHU Y.G., TANG Z., MCGRATH S.P. Soil contamination in China: current status and mitigation strategies. Environment Science Technology, 49 (2), 750, 2015.

3. BERMUDEZ G.M., JASAN R., PLÁ R., PIGNATA M.L. Heavy metals and trace elements in atmospheric fallout: their relationship with topsoil and wheat element composition. Journal of Hazardous Materials, 213-214, 447, 2012.

4. RIZWAN M., ALI S., ABBAS T., ADREES M., ZIA-URREHMAN M., IBRAHIM M., ABBAS F., QAYYUM M.F., NAWAZ R. Residual effects of biochar on growth, photosynthesis and cadmium uptake in rice (oryza sativa) under cd stress with different water conditions. Journal of Environmental Management, 206, 676, 2017.

5. GRAY C.W., DUNHAM S.J., DENNIS P.G., ZHAO F.J., MCGRATH S.P. Field evaluation of in situ remediation of a heavy metal contaminated soil using lime and red-mud. Environmental Pollution, 142 (3), 530, 2006.

6. XU P., SUN C.X., YE X.Z., XIAO W.D., ZHANG Q., WANG Q. The effect of biochar and crop straws on heavy metal bioavailability and plant accumulation in a cd and $\mathrm{pb}$ polluted soil. Ecotoxicology \& Environmental Safety, 132, 94, 2016.

7. SYTAR O., KUMAR A., LATOWSKI D., KUCZYNSKA P., STRZAŁKA K., PRASAD M.N.V. Heavy metalinduced oxidative damage, defense reactions, and detoxification mechanisms in plants. Acta Physiologiae Plantarum, 35 (4), 985, 2013.

8. D'SOUZA R.M., DEVARAJ V.R. Induction of oxidative stress and antioxidative mechanisms in hyacinth bean under zinc stress. African Crop Science Journal, 20, 17, 2012.

9. XU Y.G., YU W.T., MA Q., ZHOU H., JIANG C.M. Toxicity of sulfadiazine and copper and their interaction to wheat (Triticum Aestivum L.) seedlings. Ecotoxicology \& Environmental Safety, 142, 250-, 2017.

10. WANG S., LIANG Y., FENG L.X., TIAN C.Y. Effects of heavy metal exposure on the growth and chlorophyll fluorescence of dunaliella salina. Marine Sciences. 2010.

11. RAMZANI R.M.A., R., COYNE M.S., ANJUM S., KHAN W.U.D., IQBAL M. In situ immobilization of cd by organic amendments and their effect on antioxidant enzyme defense mechanism in mung bean (vigna radiata) seedlings. Plant Physiology \& Biochemistry, 118, 561, 2017.

12. BAILLY C. Active oxygen species and antioxidants in seed biology. Seed Science Research, 14, 93,. 2004.

13. MAXWELL K., JOHNSON G.N. Chlorophyll fluorescence - a practical guide. Journal of Experimental Botany, 51 (345), 659, 2000.

14. KANOUN-BOULÉ M., VICENTE J.A., NABAIS C., PRASAD M.N., FREITAS H. Ecophysiological tolerance of duckweeds exposed to copper. Aquatic Toxicology, 91 (1), 1, 2009.

15. MALEVA M.G., NEKRASOVA G.F., MALEC P., PRASAD M.N., STRZAŁKA K. Ecophysiological tolerance of elodea canadensis to nickel exposure. Chemosphere, 77 (3), 392, 2009.

16. LIANG X.F, HAN J., XU Y.M SUN Y.B., WANG L., TAN $\mathrm{X}$. In situ field-scale remediation of $\mathrm{Cd}$ polluted paddy soil using sepiolite and palygorskite. Geoderma, 235, 9, 2014.

17. TANG Y. An investigation of heavy-metal concentration in soil and the agricultural products content of heavy metals in a zinc lead mining area in Ganluo County of Sichuan Province. Sichuan Agricultural Uniersity. 2008.

18. WANG Z.Q., ZHANG R.J., MA J.H. Preparation and dsorption property for $\mathrm{cr} \sim(6+)$ of kh-550 modified attapulgite. New Chemical Materials, 41 (6), 84, 2003.

19. ZHAO N.N., GUGGENBERGER G., SHIBISTOVA O., THAO D.T., SHI W.J., LI X.G. Aspect-vegetation complex effects on biochemical characteristics and decomposability of soil organic carbon on the eastern qinghai-tibetan plateau. Plant \& Soil, 384 (1-2), 289, 2014.

20. MULÈ P., MELIS P. Methods for remediation of metal contaminated soils: preliminary results. Communications in Soil Science \& Plant Analysis, 31, 3193, 2000

21. BIAN, S.M, JIANG, Y.W. Reactive oxygen species, antioxidant enzyme activities and gene expression patterns in leaves and roots of kentucky bluegrass in response to drought stress and recovery. Scientia Horticulturae, 120 (2), 264, 2009.

22. LIU C., WANG Y., PAN K., LI W., ZHANG L., SHEN X., LI L., DENG M. Responses of the antioxidant defense system to drought stress in the leaves of Fargesia denudata seedlings, the staple food of the giant panda. Russian Journal of Plant Physiology, 61 (3), 374, 2014.

23. CAKMAK I., MARSCHNER H. Magnesium deficiency and high light intensity enhance activities of superoxide dismutase, ascorbate peroxidase, and glutathione reductase in bean leaves. Plant Physiology, 98 (4), 1222, 1992.

24. MADAMANCHI N.R., ALSCHER R.G. Metabolic bases for differences in sensitivity of two pea cultivars to sulfur dioxide, Plant Physiology., 97, 88, 1991.

25. GIANNOPOLITIS C.N., RIES S.K. Superoxide dismutases, 1: occurrence in higher plants [corn, oats, peas]. Plant Physiology, 59 (2), 309,. 1977.

26. BILGER W.G., BJÖRKMAN O. Role of xanthophyll cycle in photoprotection elucidated by measurements of light-induced absorbance changes, fluorescence and photosynthesis in leaves of Hedera canariensis. Photosynthesis Research, 25 (3), 173, 1990.

27. UWAH E.I., NDAHI N.P., OGUGBUAJA V.O. Study of the levels of some agricultural pollutants in soils, and water leaf (Talinum triangulare) obtained in maiduguri, nigeria. Journal of Applied Sciences in Environmental Sanitation, 4 (2), 71, 2009.

28. ZAYED A., GOWTHAMAN S., TERRY N. Phytoaccumulation of trace elements by wetland Plants: I. Duckweed. Journal of Environmental Quality, 27 (3), 715, 1998.

29. GUO G.H., LEI M., CHEN T.B., YANG J.X. Evaluation of different amendments and foliar fertilizer for immobilization of heavy metals in contaminated soils. Journal of Soils \& Sediments, 18 (1), 239, 2017.

30. MATHUR S.S., DZOMBAK D.A. Surface complexation modeling: goethite. Interface Science \& Technology, 11 (6), 443, 2006. 
31. LIANG X.F., QIN X., HUANG Q.Q., HUANG R., YIN X.L., CAI Y.M., WANG L., SUN Y.B., XU Y.M. Remediation mechanisms of mercapto-grafted palygorskite for cadmium pollutant in paddy soil. Environmental Science \& Pollution Research, 24 (30), 1, 2017.

32. HASSAN M., MANSOOR S. Oxidative stress and antioxidant defense mechanism in mung bean seedlings after lead and cadmium treatments. Turkish Journal of Agriculture \& Forestry, 38(1), 55, 2013.

33. DJANAGUIRAMAN M., SHEEBA J.A., DEVI D.D., BANGARUSAMY U.M Cotton leaf senescence can be delayed by nitrophenolate spray through enhanced antioxidant defence system. Journal of Agronomy \& Crop Science, 195 (3), 213, 2009.

34. ZONG H.Y., LIU S., XING R.G., CHEN X.L., LI P.C. Protective effect of chitosan on photosynthesis and antioxidative defense system in edible rape (Brassica rapa L.) in the presence of cadmium. Ecotoxicology and Environmental Safety, 138, 271, 2017.
35. LINGER P., OSTWALD A., HAENSLER J. Cannabis sativa, L. growing on heavy metal contaminated soil: growth, cadmium uptake and photosynthesis. Biologia Plantarum, 49 (4), 567, 2005.

36. CENKCI S., CIĞERCI İ.H., YILDIZ M., ÖZAY C., BOZDAĞ A., TERZI H. Lead contamination reduces chlorophyll biosynthesis and genomic template stability in brassica rapa. L. Environmental \& Experimental Botany, 67 (3), 467, 2010

37. VERNAY P., CÉCILE G.M., HITMI A. Interaction of bioaccumulation of heavy metal chromium with water relation, mineral nutrition and photosynthesis in developed leaves of lolium perenne, Chemosphere, 68 (8), 1563, 2007.

38. PARK B.Y., LEE J.K., RO H.M., KIM Y.H. Effects of heavy metal contamination from an abandoned mine on tomato growth and root-knot nematode development. Plant Pathology Journal, 27 (3), 1235, 2011. 